\title{
The Analysis of Company Decisions in Choosing Sukuk and Bonds Using Logit Model
}

\author{
Sukma Kukuh Pribadi \\ Universitas Indonesia \\ email: sukma.kukuh@gmail.com
}

\author{
Buddi Wibowo \\ Universitas Indonesia \\ email: wibowo_buddi@yahoo.com
}

\begin{abstract}
Sukuk has become one of alternative financing for corporate. The development of Sukuk provides the flexibility choices of company's funding decisions that required their needs and capabilities. Sukuk market in Indonesia is the second largest in emerging East Asia in terms of size but the number of issued Sukuk lower than a conventional bond. This study aims to obtain empirical evidence that the characteristics of the company influence the decision of the company in issuing Sukuk and bonds using the logit model. The results of this study conclude: (1) leverage has a negative influence and significant (2) size of the firm has a positive influence and significant (3) fixed assets has a positive influence and significant to the decision of the company in issuing Sukuk.
\end{abstract}

Keywords: Sukuk; Bonds; Financing Company Decisions; Characteristic Company; Logit Model

\begin{abstract}
Abstrak: Sukuk telah menjadi salah satu alternatif pembiayaan bagi perusahaan. Pengembangan Sukuk memberikan pilihan fleksibilitas dari keputusan pendanaan perusahaan yang membutuhkan kebutuhan dan kemampuan mereka. Pasar sukuk di Indonesia adalah yang terbesar kedua di Asia Timur dalam hal ukuran tetapi jumlah sukuk yang diterbitkan lebih rendah dari obligasi konvensional. Penelitian ini bertujuan untuk memperoleh bukti empiris bahwa karakteristik perusahaan mempengaruhi keputusan perusahaan dalam menerbitkan sukuk dan obligasi menggunakan model logit. Hasil penelitian ini menyimpulkan: (1) leverage memiliki pengaruh negatif dan signifikan (2) ukuran perusahaan memiliki pengaruh positif dan signifikan (3) aktiva tetap memiliki pengaruh positif dan signifikan terhadap keputusan perusahaan dalam menerbitkan Sukuk.
\end{abstract}

Kata Kunci: Sukuk; Obligasi; Keputusan Perusahaan Pembiayaan; Perusahaan Karakteristik; Model Logit

Economica: Jurnal Ekonomi Islam - Volume 10, Nomor 1 (2019) 


\section{Introduction}

Funding is something important to be able to develop its business for the company. There are two main models of the world financial system for corporations to obtain funding sources, bank-based systems, and marketbased systems. In some developed countries, the role of the capital market is very large in supporting corporate funding needs and even the capital market has become the foundation of the country's business and economy. Many capital market instruments are known as funding sources, namely stocks and bonds.

In addition to the increase in the conventional financial industry, the global Islamic finance industry has continued to increase over the past 20 years in both Muslim-majority and non-Muslim countries. The types of products and financial instruments based on sharia principles have also been circulating. One of them is sharia-based bonds known as Sukuk. Sukuk issuance was first started in Bahrain in 2001. The issuance of Sukuk was then followed by Britain which issued Sukuk in 2014. The UK is even committed to making its country the center of the world financial system and the center of Islamic finance in the western world. In general, the principles and concepts of Sukuk issuance resemble the principles and concepts of conventional bond issuance. The difference lies in the product, the mechanism of issuance and the use of funds that must be in accordance with sharia principles.

Based on the Islamic Finance Development Report in 2017 the total assets of the Islamic finance industry amounting to USD 2,202 billion at the end of 2016 and Sukuk ranked the second largest with a value of USD 344.77 billion or $16 \%$ of the total assets of the Islamic finance industry (Thomson Reuters 2017). Indonesia contributed USD 81.839 billion or around $11.5 \%$ of the total world Islamic financial assets. With the value of these assets, 
Indonesia is in the seventh position as the largest country that has a contribution to the Islamic finance industry.

The development of the capital market industry, especially the bond or bond market in Indonesia, is increasingly conducive and increasing in 2017. This increase can be seen from the value of new issuance of corporate bonds in 2017 which reached 161.36 trillion rupiah or an increase of $40.23 \%$ from 2016 of 115.06 trillion rupiah. The total value of new bonds is dominated by issuers from the financial sector with a value of 97 trillion rupiah or $60 \%$ of the total new issuance nominal.

Compared to conventional bonds, in Indonesia, Sukuk is still a new thing. Sukuk issuance is still considered less popular than the issuance of bonds. According to the Islamic Finance Development Report in 2017, in terms of issuance, Indonesian Sukuk is ranked 10th, while the first position is occupied by Malaysia. As of the end of 2017, the value of Sukuk issuance in the global market reached a value of USD 99.5 billion. Indonesia ranked 5th as the country with the largest outstanding Sukuk value or by $7.3 \%$. The first position is occupied by Malaysia which is followed by Saudi Arabia and the UAE by becoming the country with the largest market share when viewed from the total outstanding Sukuk in the world. The first Sukuk issuer in Malaysia, namely Shell MDS Sdn. Bhd in 1990.

In the past 5 years, corporate Sukuk issuance in Indonesia has continued to increase. Until the end of December 2017, the Financial Services Authority $(\mathrm{OJK})$ recorded a total accumulation of corporate Sukuk that had been issued in Indonesia as many as 137 Sukuk, an increase of $24.5 \%$ from the previous year. The total nominal value of accumulated Sukuk issuance during 2017 was IDR 26.39 trillion. While the number of outstanding Sukuk (outstanding) until the end of December 2017 recorded 79 corporate Sukuk from 37 issuers with a nominal value of 15.7 trillion rupiah or an increase of $32.49 \%$ (YTD).

Economica: Jurnal Ekonomi Islam - Volume 10, Nomor 1 (2019)

http://journal.walisongo.ac.id/index.php/economica 
In general, Sukuk issuance contracts used in issuing corporate Sukuk in Indonesia are Ijarah and Mudharabah contracts. Matters related to Sukuk issuance have been regulated and in accordance with the DSN-MUI fatwa No. 40/DSN-MUI/X/2003 concerning the Capital Market and General Guidelines for the Implementation of Sharia Principles in the Capital Market and three BAPEPAM-LK regulations currently the Financial Services Authority (OJK) which are related to sharia securities governing issuance, contracts, and criteria in issuing sharia securities lists (DES) which were refined in 2009 and 2012 (Dewan Syariah Nasional 2003). In Indonesia, DSN-MUI is an institution whose task is to establish, supervise and make guidelines for implementing fatwa related to securities or financial instruments and capital markets which are in accordance with Islamic sharia. According to OJK data, out of 79 corporate Sukuk currently in circulation, there are 62 corporate Sukuk (78.48\%) using Ijarah contracts and 17 corporate Sukuk (21.52\%) using Mudharabah contracts with a nominal value of 11.6 trillion rupiah for Ijarah and 4.14 trillion rupiah for Mudharabah.

The development of the Islamic capital market in 2018 especially in corporate Sukuk issuance is a positive thing. With the increase in the value of corporate Sukuk issuance, it is a positive trigger that will attract investors to be able to invest in the capital market profitably and lawfully. The increase in the number of corporate bonds and corporate Sukuk issuance of each country can be caused due to various factors. Factors or motives that affect the issuers in issuing corporate bonds can be in the form of internal conditions of each issuer or economic conditions in the country. Issuers also must have different and relevant motives underlying the decision to issue corporate bonds and Sukuk with various tenors, coupons, and Sukuk types as alternative sources of financing.

For companies, the development of capital market instruments for corporate and Sukuk bonds provides flexibility in the choice of funding sources that can be used in accordance with the needs and capabilities of the 
company so that the objectives can be fulfilled. The company has alternative funding through the issuance of conventional bonds or Sukuk issuance as a funding source. However, the company's motivation to issue Sukuk compared to issuing conventional bonds has not been widely studied.

Empirical studies in previous studies related to company decisions about issuing Sukuk and conventional bonds show mixed results. Johnson (1997) argues that the proportion of fixed assets in the company's balance sheet is negatively related to the proportion of non-bank debt. This shows that financial institutions, especially non-banks, are riskier companies compared to other companies. Whereas, Denis and Mihov (2003) did not find a relationship between fixed assets and the possibility of loans from nonbank institutions. However, companies with investment-grade categories are more likely to like loans from banks. Carey, Post, and Sharpe (1998) provide evidence that banks serve low-risk borrowers while non-bank financial institutions better serve high-risk borrowers.

Previous research has explored many factors that influence company decisions in issuing different financial instruments. The decision of the company chosen includes the choice of the type of debt that will be issued in accordance with the characteristics of a particular company. In a study conducted by Azmat, Skully, and Brown (2014) and Mohamed, Masih, and Bacha (2015) about the choice of conventional bonds and Sukuk issuance in Malaysia, it was revealed that the choice of publishers in choosing Sukuk or conventional bonds was not the same.

Grassa and Miniaoui (2018) provides evidence that in relation to larger debt and a longer period of time, companies prefer to issue Sukuk rather than conventional bonds. While related to the quality of credit ratings, shows a positive correlation with the issuance of conventional bonds and a negative correlation with Sukuk issuance. Nagano (2016) findings show that in Malaysia, Sukuk publishers prefer this instrument to other external financing tools, and this choice is not related to the availability of internal funds. In 
addition, Sukuk issuance is considered to contribute to the increase in the company's stock profit. This means that the choice to issue Sukuk rather than conventional bonds has a significant influence on shareholder value. Therefore, in Malaysia, Sukuk issuance is preferred because of the unique benefits that standard external financing does not have.

In line with previous research, Arena and Howe (2009) also found that companies that have better credit quality in the leverage ratio and outstanding subordinated debt, are more likely to make loans from banks than to issue debt. Shirasu and Xu (2007) found that good quality Japanese companies had left the bank and switched to the bond market, while lowquality companies turned towards bank debt. Banks in Japan tend to lend to large companies.

Lin et al. (2013) studied the relationship between the ownership structure of the borrowing company and its choice to obtain a source of debt. Their findings provide evidence that the difference between the control rights and the cash flow rights of the borrowers' largest shareholders has a significant impact and a negative correlation to the company's dependence on bank debt financing.

Based on this background, this research was conducted to find out what factors influenced the company to issue sukuk and bonds and how much accuracy the logit model was used to predict the probability of a company to issue sukuk and bonds.

\section{Literature Review}

According to Harjito and Martono (2005) there are four main types of decisions that can be taken by management in financially related companies, namely (1) investment decisions (investment decisions), (2) financing decisions (financing decisions), (3) dividend distribution decisions (dividend decision) and (4) liquidity decisions (liquidity decision). In finance, capital structure is used as one way for companies to finance their assets or projects 
through several combinations of securities consisting of equity securities and debt securities. According to Hanafi and Halim (2012), there are several theories regarding capital structure including:

\section{Traditional Approach}

This approach argues that companies can change the capital structure to obtain an optimal structure. This capital structure can affect the value of the company.

\section{Modigliani-Miller Theorem}

This theory was introduced by Franco Modigliani and Merton Miller in 1958. They introduced a basic form of capital structure known today. This theorem reveals that the optimal capital structure is a capital structure that maximizes firm value. The optimal capital structure must have $99.9 \%$ debt and no equity effects.

\section{The Trade-Off Theory}

This theory reveals that there are advantages to financing using debt. The trade off theory in capital structure allows for bankruptcy costs as compensation costs in an effort to balance the benefits of using debt as a tax protector called the tax benefit of debt. This theory refers to how much equity and debt are used in financing based on costs and benefits.

\section{Pecking Order Theory}

The pecking order theory was popularized by Myers in 1984. This theory explains the hierarchy of the Company's funding sources. This theory reveals that the priority of the company's funding sources is financing originating from internal sources. When internal financing sources are no longer sufficient, the Company will issue debt securities. Financing using equity securities is used as the Company's last resort if external financing is 
needed. In this theory, the selection of issuance of debt securities can be considered as a signal that the Company needs external funding.

\section{Theory of Information Asymmetry and Signaling}

Asymmetry theory argues that parties related to the company do not have the same information about the prospects and risks of the company. There are others who have better information about the company, usually company managers. Differences between investors and managers that cause information asymmetry. Signaling theory is a theory where the capital structure is a signal that managers convey to the market. Companies that increase debt can be seen as companies that have good prospects. It is hoped that investors will raise this signal as something positive.

Bonds according to Brigham and Houston (2012) are long-term contracts where the borrower agrees to pay interest and principal loans on a certain date to the bondholders. Publisher-based bonds are divided into three types, namely: (1) regional bonds (municipal bonds), (2) government bonds, (3) corporate bonds.

Based on interest rates, bonds are divided into four types, namely: (1) zero coupon bonds, which are sold at a discounted price, but at maturity investors will receive payment of their debt in full, (2) fixed rate (FR) bonds are these bonds provide the same coupon value or fixed interest rate until the maturity date of the bond. (3) variable rate (VR) bonds are bonds whose value of coupon payment changes or uses floating interest rates throughout the period of coupon payments to maturity, (4) mixed fixed rate and variable rate bonds are types of bonds that have coupon values varying throughout period of coupon payment until maturity. For example, payment of bond coupons for the first 12 months uses a fixed interest rate and the remaining coupon payments to maturity use floating interest rates. 
Bond rating (bond rating) is a character symbol given by a bond rating agent to indicate the default risk of a bond issued. Bond ratings according to PT PEFINDO can be seen as table 1 :

Table 1. Bond Ratings

\begin{tabular}{ll}
\hline Ratings & Interpretation \\
\hline idAAA & Superior \\
\hline idAA & Very Strong \\
\hline id $\mathrm{A}$ & Strong \\
\hline idBBB & Adequate \\
\hline idBB & Somewhat weak \\
\hline idB & Weak \\
\hline id CCC & Vulnerable \\
\hline $\mathrm{id} \mathrm{D} / \mathrm{id} S \mathrm{DD}$ & Default/Selective Default \\
\hline
\end{tabular}

Source: PT PEFINDO (2018)

Based on the Accounting and Auditing Organization for Islamic Financial Institutions/(AAOIFI 2003), Sukuk is a security with the same denomination value that represents individual ownership in a portfolio of assets that meet current or future requirements (Vinnicombe 2010). According to DSN-MUI in the DSN-MUI Fatwa Number 32/DSN-MUI/IX/2002, Islamic bonds (Sukuk) as a long-term security issued by issuers based on sharia principles that require issuers to pay income in the form of profit sharing/margin/fee to Sukuk holders and promises to repay the principal at maturity.

Some types of Sukuk based on the Accounting and Auditing Organization for Islamic Financial Institutions/AAOIFI include: (1) Sukuk Mudharabah, which is Sukuk based on Mudharabah contracts, namely cooperation agreements between two or more parties, namely between 
investors or capital owners with owners services, (2) Sukuk Ijarah, namely Sukuk which is based on the Ijarah contract, namely leasing agreement on an asset, (3) Sukuk Musyarakah, which is Sukuk based on cooperation contract in combining capital and profit and loss together according to the initial contract, (4) Sukuk Istisna, which is a Sukuk based on the financing contract of a project in which the way the period of delivery of goods and the price of goods are agreed upon by the parties.

While the characteristics of Sukuk are generally owned as follows: (1) Sukuk is a certificate or proof of ownership of an tangible asset or beneficial title, (2) Has income that is profit or profit sharing, adjusted to the type of contract, (3) Activities that financed by Sukuk and all matters related to Sukuk issuance must be in accordance with sharia principles and free from elements of usury, gharar and maysir, (4) Issuance of Sukuk through Special purpose vehicle (SPV). SPV as a third party that functions as a Sukuk issuer, trustee represents investors and as a government counterpart in asset transfer transactions, (5) Sukuk must have an underlying asset.

The difference between Sukuk and conventional bonds based on the Accounting and Auditing Organization for Islamic Financial Institutions (AAOIFI) can be shown in the table 2:

Table 2. The Comparison Between Sukuk and Bond

\begin{tabular}{lll}
\hline Parameters & Sukuk & Bond \\
\hline Issuer & Government or corporate & Government or corporate \\
\hline Characters & $\begin{array}{l}\text { Ownership certificate for an } \\
\text { asset }\end{array}$ & Debt statement \\
\hline Revenue & $\begin{array}{l}\text { Profit sharing and capital gain } \\
\text { (if traded in secondary } \\
\text { market) }\end{array}$ & $\begin{array}{l}\text { Coupon and capital gain (if } \\
\text { traded in secondary market) }\end{array}$ \\
\hline Tenor & $\begin{array}{l}\text { Starting from the short to } \\
\text { medium term }\end{array}$ & $\begin{array}{l}\text { Starting from short to long } \\
\text { term }\end{array}$ \\
\hline Underlying & Require underlying asset & Does not require underlying \\
\hline
\end{tabular}


The Analysis of Company Decisions in Choosing Sukuk and Bonds ...

\begin{tabular}{|c|c|c|}
\hline Parameters & Sukuk & Bond \\
\hline asset & & assets \\
\hline Related parties & $\begin{array}{l}\text { Obligor (issuer), Special } \\
\text { Purpose Vehicle (SPV), and } \\
\text { investor }\end{array}$ & $\begin{array}{l}\text { Issuer, trustee, underwriter, } \\
\text { and investor. }\end{array}$ \\
\hline Price & Market price & Market price \\
\hline $\begin{array}{l}\text { Payment par } \\
\text { value }\end{array}$ & Bullet or amortization & Bullet or amortization \\
\hline $\begin{array}{l}\text { Utilization of } \\
\text { fund }\end{array}$ & $\begin{array}{l}\text { In accordance with sharia } \\
\text { principles }\end{array}$ & free \\
\hline
\end{tabular}

Source: (AAOIFI 2015)

\section{Methods}

\section{Sources and Research Methods}

This study uses descriptive analysis research design that is by explaining the results obtained from data collected and processed and tested and analyzing the relationships that occur between the variables studied. This research is a quantitative method where the data obtained is secondary data in the form of Sukuk and bond data from 2013 to 2017 which are still outstanding and other secondary data such as financial statements from each company.

The research uses Sukuk and corporate bonds data that are published and still circulating from 2013 to 2017 obtained from the Indonesia Bond Pricing Agency (IBPA). Furthermore, the researcher uses audited financial statements from each company to obtain the required data in accordance with the research variables. After data collection and processing is carried out, 68 data of Sukuk and 415 bonds are obtained, so that the data is adjusted to the research variables. This study aims to look at variables that affect companies in issuing Sukuk and bonds. 


\section{Model Logit}

The analysis used in this study is logistic binary regression using the logit model. The logit model is a non-linear probability econometric regression method, where the dependent variable is a dummy variable that follows the logistic distribution function. The logit model is used to be able to test the probability of the dependent variable with the independent variable. This study uses this model because it has 2 (two) categories in the dependent variable. The dependent variable in this study is the probability of the company to decide on the use of funding from Sukuk or bonds. The researcher uses a dummy value to determine if the company uses Sukuk and if the company uses bonds. Dummy Sukuk or bond variable as follows:

$\mathrm{P}=0$; If company choose bonds; and

$\mathrm{P}=1$; If company choose sukuk.

The independent variables examined in this study were 12 independent variables. The free variables are as table 3 :

Table 3. The Independent Variables

\begin{tabular}{lll}
\hline Variables & Description & Measurement \\
\hline Size & Issuance Size & Log of total amount issued \\
\hline Tenor & Issuance Tenor & Number of years \\
\hline Rating & Credit Rating & $\begin{array}{l}\text { Issuance rating based on } \\
\text { PEFINDO }\end{array}$ \\
\hline Leverage & Leverage & Debt Equity Ratio (DER) \\
\hline Age & Age & Issuer age \\
\hline Leverage Ratio & Leverage Ratio & Long term debt/total assets \\
\hline Firm Size & Firm Size & Log of total assets \\
\hline Earning Growth & Earning Growth & EG $=\frac{\text { EBIT }_{\mathrm{t}}-\mathrm{EBIT}_{\mathrm{t}-1}}{\text { EBIT }_{\mathrm{t}-1}} \times 100$ \\
\hline Sales Growth & Sales Growth & $\mathrm{SG}=\frac{\text { Sales }_{\mathrm{t}}-\text { Sales }_{\mathrm{t}-1}}{\text { Sales }_{\mathrm{t}-1}} \times 100$ \\
\hline
\end{tabular}


The Analysis of Company Decisions in Choosing Sukuk and Bonds ...

\begin{tabular}{lll}
\hline Variables & Description & Measurement \\
\hline Return on Assets (ROA) & ROA & ROA $=\frac{\text { Net Income }}{\text { Total Aset }} \times 100$ \\
\hline Fixed Assets & Fixed Assets & $\begin{array}{l}\text { Based On Company's Financial } \\
\text { Statements }\end{array}$ \\
\hline Cash Flow & Cash Flow & $\begin{array}{l}\text { Based On Company's Financial } \\
\text { Statements }\end{array}$ \\
\hline
\end{tabular}

The independent variables in this study will be used in the logit model, namely : (i) Size ; (ii) Tenor ; (iii) Rating ; (iv) Leverage ; (v) Umur Perusahaan ; (vi) Leverage Ratio; (vii) Ukuran Perusahaan; (viii) Earning Growth; (ix) Sales Growth ; (x) Return on Assets; (xi) Fixed Assets; dan (xii) Cash Flow.

The model in this study is to determine the probability (tendency) of free variables that can influence the company's decision to issue Sukuk and bonds. Based on the number of variables examined, the logit model that will be used in this study is as follows:

$$
\begin{aligned}
\operatorname{Ln}(p / 1-p) & =\alpha+\beta_{1} \text { SIZE }+\beta_{2} \text { TENOR }+\beta_{3} \text { RATING }+\beta_{4} \text { LEV }+\beta_{5} \\
& \text { AGE }+\beta_{6} \text { LTDA }+\beta_{7} \text { LA }+\beta_{8} \text { EG }+\beta_{9} \text { SG }+\beta_{10} \text { ROA } \\
& +\beta_{11} \text { FA }+\beta_{1}+\varepsilon
\end{aligned}
$$

The probability value in the logit model can be explained as follows:

$$
L i=\ln \left(\frac{p i}{1-p i}\right)=\beta 1
$$

\section{Research Samples}

Not all Sukuk and bonds recorded in the 2013 to 2017 period meet the requirements to be sampled because companies that issue Sukuk or bonds do not have complete financial report data. And based on predetermined 
Sukma Kukuh Pribadi, Buddi Wibowo

criteria obtained 68 Sukuk and 415 bonds to be sampled. The sample selection process is shown in table 4:

Table 4. Samples Selection

\begin{tabular}{lc}
\hline Criteria & N \\
\hline $\begin{array}{l}\text { Registered and outstanding sukuk and bond on The } \\
\text { Indonesia Stock Exchange from } 2013 \text { to } 2017\end{array}$ & 527 \\
\hline Sukuk or bond that does not have financial report data. & $(44)$ \\
\hline Total & $\mathbf{4 8 3}$ \\
\hline
\end{tabular}

Source: Indonesian Bond Pricing Agency (2017)

\section{Descriptive Statistics}

Based on the results of data processing using SPSS 25, descriptive results were obtained which illustrated simply the independent variables tested in this study. Descriptive analysis of the independent variables studied can be seen in Table 5 .

Table 5. Descriptive Statistics

\begin{tabular}{lrrrrr}
\hline & N & Minimum & Maximum & Mean & Std. Deviation \\
\hline $\begin{array}{l}\text { Size (in trillion } \\
\text { rupiah) }\end{array}$ & 483 & 22.5638 & 29.1250 & 26.714080 & 1.1362924 \\
\hline Tenor & 483 & 1 & 30 & 4.88 & 2.653 \\
\hline Rating & 483 & 1 & 7 & 6.17 & 1.040 \\
\hline LEV & 483 & .0091 & .9365 & .679777 & .1945440 \\
\hline AGE & 483 & 3 & 159 & 43.84 & 30.706 \\
\hline LTDA & 483 & .0010 & 1.1212 & .290200 & .2377237 \\
\hline LA & 483 & 27.6679 & 34.8277 & 31.409670 & 1.7211508 \\
\hline EG & 483 & -39.0153 & 2.1586 & -.480485 & 4.7025019 \\
\hline SG & 483 & -.9738 & 1.3126 & .088048 & .2221677 \\
\hline ROA & 483 & -.0496 & 9.0361 & .475400 & 1.2539524 \\
\hline
\end{tabular}


The Analysis of Company Decisions in Choosing Sukuk and Bonds ...

\begin{tabular}{lcrrrr}
\hline & N & Minimum & Maximum & Mean & Std. Deviation \\
\hline $\begin{array}{l}\text { FA (in trillion } \\
\text { rupiah) }\end{array}$ & 483 & .0069 & 1204.5684 & 45.950987 & 194.4849467 \\
\hline $\begin{array}{l}\text { CF (in trillion } \\
\text { rupiah) }\end{array}$ & 483 & .0000 & 42.2920 & 4.391655 & 8.9824725 \\
\hline \begin{tabular}{l} 
Valid N (listwise) \\
\hline
\end{tabular} & 483 & & & & \\
\hline
\end{tabular}

Sumber : Data penelitian yang diolah

\section{Research Hypothesis}

This study will test the Goodness of Fit by using the Hosmer and Lemeshow Test $\mathrm{H}_{0} \mathrm{p}$ with the $\mathrm{H}_{0}$ acceptability criteria if the significance value (p-value) is obtained $>$ from the specified level (significant level) ( $\alpha$ ). In addition, this study also assessed the model and the accuracy of the use of the logit model. In addition, this study will also test the hypothesis to explain the significance of parameters in the model using the Wald test with the following hypothesis:

$\mathrm{H}_{1} \quad$ : Size significantly predicts a company to issue Sukuk or bonds.

$\mathrm{H}_{2}$ : Tenor is significant for predicting a company to issue Sukuk or bonds.

$\mathrm{H}_{3}$ : Significant rating to predict a company to issue Sukuk or bonds.

$\mathrm{H}_{4}$ : Significant leverage to predict a company to issue Sukuk or bonds.

$\mathrm{H}_{5}$ : The age of the company is significant to predict a company to issue Sukuk or bonds.

$\mathrm{H}_{6}$ : Leverage Ratio is significant to predict a company to issue Sukuk or bonds.

$\mathrm{H}_{7}$ : Company size is significant for predicting a company to issue Sukuk or bonds.

$\mathrm{H}_{8}$ : Earning Growth The company is significant to predict a company to issue Sukuk or bonds. 
$\mathrm{H}_{10}$ : Sales Growth The company is significant to predict a company to issue Sukuk or bonds.

$\mathrm{H}_{11}$ : Return on Assets The company is significant to predict a company to issue Sukuk or bonds.

$\mathrm{H}_{12}$ : Company Fixed Assets are significant to predict a company to issue Sukuk or bonds.

$\mathrm{H}_{13}$ : Cash Flow The company is significant to predict a company to issue Sukuk or bonds.

\section{Result and Discussion}

\section{The Analyst of Model Logit}

The assessment of a model can be seen from the log likelihood value in block 0 (beginning block) and block 1 (method). A model is said to be good if the $\log$ likelihood value in block $0>\log$ likelihood value in block 1 . The log likelihood analysis results can be seen in Table 6 .

Table 6. Log Likelihood Block 0 (Beginning Block)

\begin{tabular}{|c|c|c|c|}
\hline \multicolumn{4}{|c|}{ Iteration Historya,b,c } \\
\hline \multirow{2}{*}{ Iteration } & & \multirow{2}{*}{-2 Log likelihood } & Coefficients \\
\hline & & & Constant \\
\hline \multirow[t]{4}{*}{ Step 0} & 1 & 401.396 & -1.437 \\
\hline & 2 & 392.674 & -1.767 \\
\hline & 3 & 392.572 & -1.808 \\
\hline & 4 & 392.572 & -1.809 \\
\hline
\end{tabular}

a. Constant is included in the model.

b. Initial -2 Log Likelihood: 392.572

c. Estimation terminated at iteration number 4 because parameter estimates changed by less than.001. 
The Analysis of Company Decisions in Choosing Sukuk and Bonds ...

Table 7. Log Likelihood Block 1 (Method)

\begin{tabular}{cccc}
\hline Step & $\begin{array}{c}-2 \text { Log } \\
\text { likelihood }\end{array}$ & $\begin{array}{c}\text { Cox \& Snell R } \\
\text { Square }\end{array}$ & $\begin{array}{c}\text { Nagelkerke R } \\
\text { Square }\end{array}$ \\
\hline 1 & $268.180^{\mathrm{a}}$ & .227 & .408 \\
\hline
\end{tabular}

From the results of the SPSS as shown in table 7, the log likelihood value in block 0 was $392,572>\log$ likelihood in block 1 of 268,180 . So that it can be said that the logit model is good model. Based on Table 7, it can be seen that the value of Nagelkerke R2 which describes the relationship between the dependent variables can be explained by the independent variable. The interpretation of this value is equal to R2 in multiple regression, which means that the variability of the independent variable in this model is $40.8 \%$ and $59.2 \%$ is the other independent variables outside the model.

After the result of logit model is good, then the Hosmer and Lemeshow Test are carried out to test the Goodness of Fit and determine whether the formed logit model is correct or not. The value of the Goodness of Fit from the data can be seen from the Hosmer and Lemeshow Test as in Table 8.

Table 8. Hosmer anda Lemeshow Test

\begin{tabular}{cccc}
\hline Step & Chi-square & Df & Sig. \\
\hline 1 & 4.984 & 8 & .759 \\
\hline
\end{tabular}

The model made also needs to be tested for its performance by calculating the accuracy of the predictions and errors produced. The logit model in this study was formed based on the cut-off value of 0.5. The cut off value is a limiter in the dependent variable. In this study, it can be interpreted that the cut-off value is a barrier between companies that choose Sukuk and companies that choose bonds. The results of the logit model statistics with a cut off value of 0.5 can be seen in the following table 9 :

Economica: Jurnal Ekonomi Islam - Volume 10, Nomor 1 (2019) 
Sukma Kukuh Pribadi, Buddi Wibowo

Table 9. Classification Table

\begin{tabular}{|c|c|c|c|c|}
\hline \multirow{3}{*}{\multicolumn{2}{|c|}{ Observed }} & \multicolumn{3}{|c|}{ Predicted } \\
\hline & & \multicolumn{2}{|c|}{ Types } & \multirow{2}{*}{ Percentage Correct } \\
\hline & & Obligasi & Sukuk & \\
\hline \multirow[t]{2}{*}{ Types } & Obligasi & 399 & 16 & 96.1 \\
\hline & Sukuk & 44 & 24 & 35.3 \\
\hline \multicolumn{2}{|c|}{ Overall Percentage } & & & 87.6 \\
\hline
\end{tabular}

\section{a. The cut value is.500}

After analyzing using the logit model by using a cut off value of 0.5 , it is obtained a prediction data in the company's decision to issue Sukuk or bonds. It can be seen that from a total sample of 483, the model is able to predict the company's decision to issue bonds as much as 399 bonds with an accuracy percentage value of $96.1 \%$. Whereas from a total of 483 samples, the model was able to predict the company's decision to issue Sukuk as many as 24 Sukuk with an accuracy percentage value of $35.3 \%$. So that when compared to the company's decision to issue bonds or Sukuk, the exact percentage of the model is $87.6 \%$.

\section{Significance Parameters Test}

Testing the significance of parameters in the model was carried out by Wald Test. By using SPSS 25, the test results can be seen in table 10:

Table 10. Variables in the Equation

\begin{tabular}{lllrrrrr}
\hline & & \multicolumn{1}{c}{ B } & \multicolumn{1}{c}{ S.E. } & \multicolumn{1}{c}{ Wald } & \multicolumn{1}{c}{ Df } & \multicolumn{1}{c}{ Sig. } & \multicolumn{1}{c}{$\operatorname{Exp(B)}$} \\
\hline \multirow{3}{*}{ Step 1a } & Size & -.931 & .148 & 39.722 & 1 & .000 & .394 \\
\cline { 2 - 8 } & Tenor & -.010 & .072 & .021 & 1 & .885 & .990 \\
\cline { 2 - 8 } & Rating & -.126 & .211 & .352 & 1 & .553 & .882 \\
\cline { 2 - 8 } & LEV & -3.611 & .965 & 13.986 & 1 & .000 & .027 \\
\cline { 2 - 8 } & AGE & -.003 & .008 & .173 & 1 & .677 & .997 \\
\hline
\end{tabular}


The Analysis of Company Decisions in Choosing Sukuk and Bonds ...

\begin{tabular}{lrrrrrr}
\hline LTDA & .011 & 1.045 & .000 & 1 & .991 & 1.011 \\
\hline LA & .676 & .191 & 12.498 & 1 & .000 & 1.966 \\
\hline EG & -.060 & .034 & 3.088 & 1 & .079 & .941 \\
\hline SG & -.335 & .900 & .139 & 1 & .710 & .715 \\
\hline ROA & -.608 & .368 & 2.726 & 1 & .099 & .544 \\
\hline FA & .004 & .004 & 1.376 & 1 & .241 & 1.004 \\
\hline CF & -.165 & .107 & 2.386 & 1 & .122 & .848 \\
\hline Constant & 5.094 & 6.263 & .662 & 1 & .416 & 163.024 \\
\hline
\end{tabular}

a. Variable(s) entered on step 1: Size, Tenor, Rating, LEV, AGE, LTDA, LA, EG, SG, ROA, FA, CF.

Based on the data above, the logit model equation in this study can be written as follows:

$$
\begin{aligned}
L(x) & =\ln \left(\frac{p}{1-p}\right) \\
& =5.094-0.931 \text { Size }-0.010 \text { Tenor }-0.126 \text { Rating } \\
& -3.611 \text { Leverage }-0.003 \text { Umur Perusahaan } \\
& +0.011 \text { Leverage Ratio }+0.676 \text { Size Perusahaan } \\
& -0.060 \text { Earning Growth }-0.335 \text { Sales Growth } \\
& -0.608 \text { ROA }+0.004 \text { Fixed Assets }-0.165 \text { Cash FLow }
\end{aligned}
$$

The established logit model can be used to predict the company's decision whether to issue Sukuk or bonds. Using data from one Sukuk sample, the simulation will be carried out as follows:

$$
\begin{aligned}
\left(\frac{p}{1-p}\right) & =e^{-1.8541} \\
p & =\left(\frac{e^{-1.8541}}{1-e^{-1.8541}}\right)=0.1857=18.57 \%
\end{aligned}
$$

Based on the calculation above the probability value of the company choosing Sukuk compared to the bonds using the model is $18.57 \%$. 


\section{Proof Hypothesis}

After all the stages in the research are carried out, then the next step is to prove the hypothesis through hypothesis testing with a significance value at $\alpha=5 \%$ (see table 11 ).

Table 11. Hypothesis Testing Results.

\begin{tabular}{|c|c|c|c|}
\hline Hypothesis & Variable & Measurement & Result \\
\hline 1 & Size & Log of total amount issued & $\mathrm{H}_{0}$ rejected \\
\hline 2 & Tenor & Number of years & $\mathrm{H}_{0}$ accepted \\
\hline 3 & Rating & Issuance rating based on PEFINDO & $\mathrm{H}_{0}$ accepted \\
\hline 4 & Leverage & Debt Equity Ratio (DER) & $\mathrm{H}_{0}$ rejected \\
\hline 5 & Age & Issuer age & $\mathrm{H}_{0}$ accepted \\
\hline 6 & Leverage Ratio & Long term debt/total assets & $\mathrm{H}_{0}$ accepted \\
\hline 7 & Firm Size & Log of total assets & $\mathrm{H}_{0}$ rejected \\
\hline 8 & Earning Growth & $\mathrm{EG}=(\operatorname{EBIT}(\mathrm{t})-\mathrm{EBIT}(\mathrm{t}-1)) / \operatorname{EBIT}(\mathrm{t}-1) \times 100$ & $\mathrm{H}_{0}$ accepted \\
\hline 9 & Sales Growth & $\begin{array}{l}S G=\left(\text { Sales_}_{-}(\mathrm{t})-\operatorname{Sales}(\mathrm{t}-1)\right) / \text { Sales_(t-1) } \mathrm{x} \\
100\end{array}$ & $\mathrm{H}_{0}$ accepted \\
\hline 10 & Return on Assets & $\mathrm{ROA}=($ Net Income $) /($ Total Aset $) \times 100$ & $\mathrm{H}_{0}$ accepted \\
\hline 11 & Fixed Assets & Based On Company's Financial Statements & $\mathrm{H}_{0}$ accepted \\
\hline 12 & Cashflow & Based On Company's Financial Statements & $\mathrm{H}_{0}$ accepted \\
\hline
\end{tabular}

\section{Conclusion}

The variables in the study have a diverse influence on the decisions of companies in issuing Sukuk. Variable size, tenor, rating, leverage, company age, earnings growth, sales growth, return on assets, and cash flow have a negative influence on the company's decision to issue Sukuk. While the variable leverage ratio, company size, and fixed assets have a positive effect on the tendency of companies to issue Sukuk.

Of the various variables studied only 3 (three) variables that significantly influence the company's decision to issue Sukuk. These variables are the amount of nominal financing value (size) needed by the company, the 
value of the company's assets (company size) and the value of the company's Debt to Equity Ratio (DER).

In this study, the logit model proved to be the right model and was sufficient to explain the research data. The logit model can be accepted as a good estimator and can be used to predict the tendency of companies to issue Sukuk or bonds by considering the conditions and characteristics of the company. The logit model that was formed resulted in an estimated accuracy value of $87.6 \%$.

The research range is only limited to 2013 until 2017 and only Sukuk and bonds circulate in the Indonesian Capital Market. The number of samples can be added by adding a sample of years of research and research countries. For further research it is necessary to conduct in-depth studies related to non-significant variables in this study and can be added with other independent variables that can influence the company's decision to issue Sukuk or bonds. In addition, further research can also be done by comparing or using other models so that the results of the research obtained are more comprehensive.

\section{References}

AAOIFI. 2003. Accounting, Auditing and Governance Standards for Islamic Financial Institutions. Bahrain: AAOIFI.

___. 2015. "Shari'ah Standards," 1262.

Arena, Matteo P., and John S. Howe. 2009. "Takeover Exposure, Agency, and the Choice between Private and Public Debt." Journal of Financial Research 32 (2): 199-230. https://doi.org/10.1111/j.14756803.2009.01248.x.

Azmat, Saad, Michael Skully, and Kym Brown. 2014. "Issuer's Choice of Islamic Bond Type." Pacific Basin Finance Journal 28: 122-35. https://doi.org/10.1016/j.pacfin.2013.08.008.

Brigham, and Houston. 2012. Dasar-Dasar Manajemen Keuangan Edisi V. Jakarta: Salemba Empat.

Economica: Jurnal Ekonomi Islam - Volume 10, Nomor 1 (2019) 
Sukma Kukuh Pribadi, Buddi Wibowo

Carey, Mark, Mitch Post, and Steven A. Sharpe. 1998. "Does Corporate Lending by Banks and Finance Companies Differ? Evidence on Specialization in Private Debt Contracting." Journal of Finance 53 (3): 845-78. https://doi.org/10.1111/0022-1082.00037.

Denis, David J., and Vassil T. Mihov. 2003. "The Choice among Bank Debt, Non-Bank Private Debt, and Public Debt: Evidence from New Corporate Borrowings." Journal of Financial Economics 70 (1): 3-28. https://doi.org/10.1016/S0304-405X(03)00140-5.

Dewan Syariah Nasional. 2003. "Pasar Modal Dan Pedoman Umum Penerapan Prinsip Syariah Di Bidang Pasar Modal," 1-8.

Grassa, Rihab, and Hela Miniaoui. 2018. "Corporate Choice between Conventional Bond and Sukuk Issuance Evidence from GCC Countries." Research in International Business and Finance 45 (July): 454-66. https://doi.org/10.1016/j.ribaf.2017.07.179.

Hanafi, Mamduh M., and Abdul Halim. 2012. Analisis Laporan Keuangan Edisi 4. Yogyakarta: UPP STIM YPKN.

Harjito, Agus, and S. U Martono. 2005. Manajemen Keuangan. 2nd ed. Yogyakarta: Penerbit Ekonisia Kampus Fakultas Ekonomi UII.

Indonesian Bond Pricing Agency. 2017. "Bond Information and Pricing Services." 2017. http://newbips.ibpa.co.id/Information/HistoricalPriceYield/Corporate Bond/Series.aspx.

Johnson, Shane A. 1997. "An Empirical Analysis of the Determinants of Corporate Debt Ownership Structure." The Journal of Financial and Quantitative Analysis 32 (1): 47. https://doi.org/10.2307/2331316.

Lin, Chen, Yue Ma, Paul Malatesta, and Yuhai Xuan. 2013. "Corporate Ownership Structure and the Choice between Bank Debt and Public Debt." Journal of Financial Economics 109 (2): 517-34. https://doi.org/10.1016/j.jfineco.2013.03.006.

Mohamed, Hisham Hanifa, Mansur Masih, and Obiyathulla I. Bacha. 2015. "Why Do Issuers Issue Sukuk or Conventional Bond? Evidence from Malaysian Listed Firms Using Partial Adjustment Models." Pacific Basin Finance Journal 34: 233-52. https://doi.org/10.1016/j.pacfin.2015.02.004. 
Nagano, Mamoru. 2016. "Who Issues Sukuk and When?: An Analysis of the Determinants of Islamic Bond Issuance." Review of Financial Economics 31: 45-55. https://doi.org/10.1016/j.rfe.2016.05.002.

PT PEFINDO. 2018. “Definisi Peringkat Efek," no. August.

Shirasu, Yoko, and Peng Xu. 2007. "The Choice of Financing with Public Debt versus Private Debt: New Evidence from Japan after Critical Binding Regulations Were Removed." Japan and the World Economy 19 (4): 393-424. https://doi.org/10.1016/j.japwor.2006.06.002.

Thomson Reuters. 2017. "Islamic Finance Development Report 2017: Toward Sustainability," 1-120.

Vinnicombe, Thea. 2010. "AAOIFI Reporting Standards: Measuring Compliance." Advances in Accounting 26 (1): 55-65. https://doi.org/10.1016/j.adiac.2010.02.009. 
